Short communication

\title{
EFFECTS OF $B F$ GENE POLYMORPHISM ON THE REPRODUCTIVE PERFORMANCE OF HYBRID POLISH LANDRACE X POLISH LARGE WHITE SOWS
}

\author{
NAPIERAŁA Dorota, KAWĘCKA Maria, JACYNO Eugenia, MATYSIAK Beata, \\ KOLODZIEJ-SKALSKA Anita*
}

\begin{abstract}
Department of Pig Breeding, Animal Nutrition and Food, Faculty of Biotechnology and Animal Science, West Pomeranian University of Technology in Szczecin, ul. Doktora Judyma 10, 70-466 Szczecin, Poland
\end{abstract}

(Received 30 June; Accepted 26 October 2015)

\begin{abstract}
The aim of this study was to determine the potential relationship between variants of the $B F$ gene and litter size in Polish Landrace $\mathrm{x}$ Polish Large White sows. To identify polymorphism within the $B F$ gene, the PCR-RFLP method was applied, using specific primers and the $S m a \mathrm{I}$ enzyme. The researchers identified the presence of two alleles, $\mathrm{T}$ and $\mathrm{C}$, with frequencies: 0.68 and 0.32 , giving three genotypes with frequencies: 0.49 , 0.37 and 0.14 , respectively for TT, TC and CC. Analysis of relationships between the various genotypes of the $B F$ gene and selected reproductive traits showed significant differences. Sows with TT genotype in the BF locus, gave birth to significantly more live piglets in the first litter (10.24) compared with sows with the CC genotype (7.13).
\end{abstract}

Key words: pig, $B F$ gene, reproduction, SNP, litter size

\section{INTRODUCTION}

The optimal use of the reproductive potential by obtaining large litters significantly reduces costs of pork production. According to Spötter and Distl [1], the most important of these are the numbers of piglets born and weaned per litter. Markerassisted selection (MAS), employed in conjunction with traditional selection methods, could accelerate the rate of change in economically important traits [2]. Many genes associated with litter size and other reproductive traits have been mapped on the porcine chromosomes. However, limited information on this field in conjunction with the fact that the results are inconsistent, leads to the need of further investigation in this particular area [3]. Properdin, otherwise known as Factor P (or BF), plays an important role in natural immune processes, as one of the factors of non-specific immune response. BF is classified as a class III molecule of swine leukocyte antigen (SLA), in contrast to other numerous complement protein inhibitors [4]. It has been

\footnotetext{
*Corresponding author: e-mail: anita.kolodziej@zut.edu.pl
} 
mapped near the centromeric region of chromosome 7, locus 7 1/2 p11-p12 [5]. In this area various QTL's and genes associated with reproductive characteristics are included [2,6,7]. Properdin might be one such gene which is especially important for litter size. The BF gene plays an important role in uterine epithelium growth [8] as well as in the formation of litter size in mice in interaction with other genes [9]. In studies carried out on crossbred sows a relation was revealed between the $B F$ genotype and the number of born piglets [2, 3].

The aim of the research was to determine the frequency of particular genotypes of the $B F$ gene and potential relationships between different genotypes of $B F$ gene and litter size in the herd of crossbred sows (Polish Landrace x Polish Large White).

\section{MATERIAL AND METHODS}

In this study 493 Polish Large White x Polish Landrace sows, which gave 1760 litters, were used. All animals were bred and raised at a commercial farm (West Pomeranian Region). Rearing and feeding conditions were identical for all the animals. All litters were weaned on day 30 of lactation. Sows were kept in a closed house in groups. Sows were fed complete feed mixture (according to the standard in Poland 1993). Sows were inseminated with semen of boars from the PIC Company. Blood samples were stored in a vacuum test-tube containing $\mathrm{K}_{3}$ EDTA. Genomic DNA extraction was performed from peripheral blood by using Master Pure'TM Genomic DNA Purification Kit by Epicentre Technologies ${ }^{\circledR}$ (Madison, WI, USA). Spectrophotometric analysis showed a mean concentration of DNA within $70-90 \mu \mathrm{g} / \mathrm{ml}$.

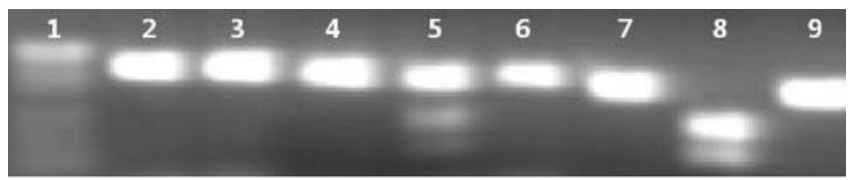

Figure 1. Products PCR-RFLP at BF gene of sows. Lane 1: DNA marker; lanes 2-4,6,7,9: 390 bp (T'T genotypes); lane 5: 390+237+153 bp (TC genotype); lane 8: 273+153 bp (CC genotype)

The polymorphic locus in BF gene was identified by the restriction enzyme SmaI, by using the polymerase chain reaction-restriction fragment-length polymorphism (PCR - RFLP) method. The primer sequences were: 5' ACT GCT ATG ACG GTT ACA CTC TCC G 3' - for the forward and 5' TCC AAG AGC CAC CT'T CCT GG 3' - for the reverse primers. Detection of $B F$ polymorphism was based on a method reported by Jiang and Gibson [10]. PCR amplification was performed by using the following conditions: After denaturation at $94{ }^{\circ} \mathrm{C}$ for $5 \mathrm{~min}, 30$ amplification cycles comprising denaturation at $94{ }^{\circ} \mathrm{C}$ for $30 \mathrm{~s}$, followed by a further 5 -min extension at $72{ }^{\circ} \mathrm{C}$ were performed and finally stored. The PCR reactions were performed in a thermocycler (Biometra). The reaction mixture contained 70 ng DNA, 10 pM of each primer, and the samples were amplified using the reaction mixture REDTaq ${ }^{\circledR}$ 
Ready MixTM (Sigma). Primer sequences were synthesized by IBB PAN in Warsaw. Evaluation of the products obtained after digestion (PCR - RFLP) was made using agarose gel electrophoresis (PRONA) at a concentration matched to the length of DNA fragments, with the addition of ethidium bromide. The results were visualized using UV light (Fig. 1).

Data regarding the litter size of sows in subsequent reproductive cycles and weaningfertile mating interval were collected, based on breeding records. The characteristics of the genetic structure of the tested sows included allele frequencies and genotypes of $B F$, and comparisons of genotype frequencies and genotypes $B F$ homo - and heterozygous gene $B F$ from the expected frequencies. In order to determine the relationships between $B F$ gene variants and the phenotypic values of the analyzed traits, analysis of variance was performed using GLM and GLZ multivariate regression methods according to the following model:

$$
\mathrm{yi}_{\mathrm{jkl}}=\mu+\mathrm{a}_{\mathrm{i}}+\mathrm{k}_{\mathrm{j}}+\mathrm{b}_{\mathrm{k}}+\mathrm{ab}_{\mathrm{ik}}+\mathrm{f}_{\mathrm{l}}+\mathrm{e}_{\mathrm{ijkl}}
$$

where: $y_{\mathrm{ijk} 1}$ - phenotypic record of NBA (number of piglets born alive), NSB (number of stillborn piglets), NW (number of piglets weaned); $\mu$ - general mean; $a_{i}$ - effect of genotype; $k_{j}$ - random effect of sire; $b_{k}$ - effect of parity number $(j=1,2) ; a b_{i k}-$ effect interaction of genotype $x$ parity number; $f_{1}$ - effect of season of birth; $e_{i j k l}$ - random error.

The significance of differences between the values of selected characteristics of reproductive performance of sows of different genotypes of the $B F$ gene was determined using multiple Duncan tests. For diallelic loci, we determined the additive and dominance effects of the gene $B F$ in relation to the number of piglets born alive. For this purpose, we used a functional model proposed by Alvarez-Castro and Carlborg [11]. The functional dominance effect was the deviation of the heterozygous genotype of the arithmetic mean of the two homozygous genotypes. All analyses were performed using Statistica PL 10.

\section{RESULTS AND DISCUSSION}

In the analyzed herd of sows, too alleles, $\mathrm{C}$ and $\mathrm{T}$, and consequently three genotypes - CC, TC and TT of the BF gene's polymorphic site were identified (Table 1). The study showed a higher frequency of allele $\mathrm{T}(0.68)$ compared with allele $\mathrm{C}(0.32)$, which resulted in a relatively high frequency of the TT genotype (0.44) compared with the second homozygous genotype CC (0.14), while the heterozygous genotype TC had a frequency of 0.37 . In a study by Buske et al. [2], in commercial crossbred sows, the frequency of the $\mathrm{T}$ allele was much higher $(0.89)$ than the allele $\mathrm{C}(0.11)$. They observed the highest frequency of T'T genotype (0.81), which was much higher than TC (0.16) and individuals with the CC genotype (0.03). A similar frequency of the $\mathrm{T}$ allele (0.86) was observed by Chinese researchers in Beijing black sows [12]. The genotyping of commercial sows in Greece revealed that none had the CC genotype, 
and the frequency of the TC genotype was 0.21 [3]. Wu et al. [13] reported a new polymorphism, a result of nonsense mutation in the exon region. Publications on the frequency of polymorphism within the BF locus in any Polish pig breeds were not found.

Table 1. The frequency of $B F / S m a$ alleles and genotypes in Polish Large White and Polish Landrace crossbred sows

\begin{tabular}{lccccccc}
\hline & \multicolumn{9}{c}{ Genotype } & \multicolumn{2}{c}{ Allele } \\
\cline { 2 - 8 } & CC & CT & TT & Homozygous & Heterozygous & C & T \\
\hline Number & 68 & 181 & 244 & 312 & 181 & 0.32 & 0.68 \\
Frequency & 0.14 & 0.37 & 0.49 & 0.63 & 0.37 & & \\
\hline
\end{tabular}

Analysis of the potential effect of individual genetic variants of the $B F$ gene on the selected reproductive traits of sows showed significant $(\mathrm{p}<0.01)$ differences in the number of piglets born alive, stillborn and weaned in a litter (Table 2). TT sows had the greatest number of piglets born alive both in the first litter $(\mathrm{p}<0.01)$. The lowest number of piglets born alive was observed in CC sows. TC sows gave birth to significantly $(\mathrm{p}<0.01)$ alive piglets compared to CC sows. The greatest number $(\mathrm{p}<0.01)$ of stillborn piglets was observed in CC sows, and the lowest in TT sows in the first litter. In the second litter the results were similar, although not significant. CC sows weaned the lowest number of piglets in the first $(p<0.01)$, second and third litter, but the difference was not significant. Buske et al. [2], showed significant differences $(p<0.05)$ of litter size against individual genotypes of the $B F$ gene. The highest total number of piglets born and born alive in TT sows, the lowest in CC sows, and intermediate in TC sows. Similarly Marantidis et al. [3] confirmed the positive effect of the allele T on the number of piglets born by TT sows, particularly between the second and fifth parity. Wang et al. [11], analyzed relations between the polymorphism of the BF locus and the litter size, showed different results than in our study and reports by Buske et al. [2]. Those authors observed the lowest total number of born and live born piglets in TT sows, although the differences were not statistically significant. Only in the number of live born piglets in litters later than the first, a statistically significant difference was observed $(\mathrm{p}<0.05)$, i.e. with the best results obtained by CT sows.

For individual alleles of the $\mathrm{BF}$ gene we calculated the value of addition and domination, and the results are presented in Table 3. In the examined locus we found a significant additive effect of the allele $\mathrm{T}$ - in the first litter TT sows had significantly more live born piglets and CC sows.

This study showed that in the first litter of sows with genotypes TT and TC in the BF locus, the number of piglets born alive was higher than in sows with genotype CC. The observed positive effect of the $T$ allele in BF locus indicates the possibility of using the tested polymorphism in improving the reproductive performance of sows. 
Table 2. Effects of $B F$ genotype on reproductive traits of Polish Large White and Polish Landrace crossbred sows

\begin{tabular}{|c|c|c|c|c|c|c|c|c|c|}
\hline \multirow[b]{2}{*}{$\begin{array}{c}B F \\
\text { Genotype } \\
\end{array}$} & \multirow[b]{2}{*}{ sows } & \multicolumn{2}{|c|}{ NBA } & \multicolumn{2}{|c|}{ NSB } & \multicolumn{2}{|c|}{ NW } & \multicolumn{2}{|c|}{ WFMI } \\
\hline & & $\bar{x}$ & SD & $\bar{x}$ & SD & $\bar{x}$ & SD & $\bar{x}$ & SD \\
\hline \multicolumn{10}{|c|}{ I parity } \\
\hline $\mathrm{CC}$ & 57 & $7.13^{\mathrm{A}}$ & 3,15 & $3.20^{\mathrm{A}}$ & 2.19 & $7.94^{\mathrm{A}}$ & 2.54 & 20.96 & 24.63 \\
\hline TC & 155 & $8.33^{\mathrm{B}}$ & 1,38 & $2.16^{\mathrm{B}}$ & 1.98 & $8.98^{\mathrm{B}}$ & 1.85 & 22.01 & 22.58 \\
\hline TT & 225 & $10.24^{C}$ & 1,38 & $1.2^{\mathrm{C}}$ & 0.46 & $8.83^{\mathrm{B}}$ & 1.39 & 19.71 & 22.74 \\
\hline$\Sigma$ & 437 & & & & & & & & \\
\hline \multicolumn{10}{|c|}{ II parity } \\
\hline $\mathrm{CC}$ & 52 & 9.52 & 2.07 & 1.76 & 1.03 & 9.31 & 1.78 & 13.31 & 15.28 \\
\hline TC & 143 & 9.76 & 1.84 & 1.47 & 0.78 & 9.35 & 1.52 & 9.07 & 13.23 \\
\hline TT & 215 & 10.10 & 2.01 & 1.56 & 0.99 & 9.74 & 1.81 & 14.35 & 18.18 \\
\hline$\Sigma$ & 410 & & & & & & & & \\
\hline \multicolumn{10}{|c|}{ III parity } \\
\hline $\mathrm{CC}$ & 50 & 10.08 & 2.67 & 1.48 & 1.04 & 9.50 & 1.47 & 14.28 & 15.47 \\
\hline TC & 124 & 10.06 & 2.17 & 1.63 & 1.00 & 9.59 & 1.72 & 11.57 & 13.78 \\
\hline TT & 192 & 10.33 & 2.18 & 1.57 & 0.94 & 9.89 & 1.40 & 12.50 & 16.77 \\
\hline$\Sigma$ & 366 & & & & & & & & \\
\hline \multicolumn{10}{|c|}{ IV $\geq$ parity } \\
\hline $\mathrm{CC}$ & 83 & 10.31 & 2.20 & 1.42 & 0.76 & 9.84 & 1.41 & 6.73 & 7.76 \\
\hline TC & 194 & 10.44 & 1.99 & 1.31 & 0.69 & 9.60 & 1.43 & 7.65 & 9.07 \\
\hline TT & 269 & 10.57 & 2.51 & 1.39 & 0.81 & 9.74 & 1.30 & 8.65 & 10.05 \\
\hline$\Sigma$ & 546 & & & & & & & & \\
\hline
\end{tabular}

$\bar{x}$ - mean values; $\mathrm{SD}$ - standard deviation; NBA - number of piglets born alive; NSB number of stillborn piglets; NW - number of piglets weaned ; WFMI - weaning-fertile mating interval; ${ }^{\mathrm{A}, \mathrm{B}}$ - mean value in the same column with different superscripts differ significantly $\mathrm{P}<$ 0.01

Table 3. Additive and dominance effect of the $B F$ alleles on NBA

\begin{tabular}{ccccccc}
\hline $\begin{array}{c}\text { Parity } \\
\text { number }\end{array}$ & Additive & SE & P & Dominance & SE & P \\
\hline I & 2.037 & 0.34 & 0.00 & -0.22 & 0.48 & 0.65 \\
II & 0.28 & 0.15 & 0.06 & -0.07 & 0.22 & 0.76 \\
III & 0.10 & 0.17 & 0.57 & -0.14 & 0.26 & 0.60 \\
IV $\geq$ parity & 0.11 & 0.14 & 0.44 & -0.01 & 0.22 & 0.98 \\
\hline
\end{tabular}

NBA - number of piglets born alive; SE - standard error; P - significance level; Values in bold statistically significant alleles effect 


\section{Authors' contributions}

All authors equally contributed to this work, read and approved the final manuscript.

\section{Declaration of conflicting interests}

The author(s) declared no potential conflicts of interest with respect to the research, authorship, and/or publication of this article.

\section{REFERENCES}

1. Spötter A, Distl O: Genetic approaches to the improvement of fertility traits in the pig. Vet Journal 2006, 172 (2): 234-247.

2. Buske B, Brunsch C, Zeller K, Reinecke P, Brockmann G. : Analysis of properdin (BF) genotypes associated with litter size in a commercial pig cross population. J Anim Breed Gen 2005, $122:$ 259-263.

3. Marantidis A, Papadopoulos A I, Michailidis G, Avdi M : Association of BF gene polymorphism with litter size in a commercial pig cross population. Anim Reprod Sci 2013,141 (1-2): 75-79.

4. Schwaeble WJ, Reid KBM: Does properdin crosslink the cellular and the humoral immune response? Immunol Today 1999, 20 (1): 17-21.

5. Ponsuksili S, Wimmers K, Yerle M, Schellander K: Mapping of 93 porcine ESTs preferentially expressed in liver. Mamm Genome 2001, 12: 869-872.

6. Wilkie PJ, Paszek AA, Beattie CW, Alexander LJ, Wheeler MB, Schook L B : A genomic scan of porcine reproductive traits reveals possible quantitative trait loci (QTLs) for number of corpora lutea. Mamm Genome 1999, 10 : 573-578.

7. De Koning DJ, Rattink AP, Harlizius B, Groenen MAM, Brascamp EW, Van Arendonk JAM, Brascamp EW: Detection and characterization of quantitative trait loci for growth and reproduction traits in pigs. Livest Prod Sci 2001, 72: 185-198.

8. Hasty LA, Brockman WW, Lambris JD, Lyttle CR: Hormonal regulation of complement factor B in human endometrium. Am J Reprod Immunol 1993, 30: 63-67.

9. Matsumoto M, Fukuda W, Circolo A, Goellner J, Strauss-Schoenberger J, Wang X, Fujita S, Hidvegi T, Chaplin DD, Colten HR: Abrogation of the alternative complement pathway by targeted deletion of murine factor B. Immun 1997, 94: 8720-8725.

10. Jiang ZH, Gibson JP: Rapid communication: A PCR-RFLP marker at the porcine complement factor B gene locus shows between-population frequency variation. J Anim Sci 1998, 76: 1716-1717.

11. Álvarez-Castro JM, Carlborg Ö: A unified model for functional and statistical epistasis and its application in quantitative trait loci analysis. Gen 2007, 176: 1151-1167.

12. Wang X, Wang L, Luo Reng Z, Sun S: Analysis of PRLR and BF genotypes associated with litter size in Beijing Black Pig Population. Agr Sci China 2008, 7 (11): 1374-1378.

13. Wu Y., Chen Y., Liu R., 2011 - Analysis of polymorphism for porcine properdin (BF) in Qianbei black pig population. Guandong Agric Sci 4: 882-892. 


\title{
EFEKTI POLIMORFIZMA BF GENA NA REPRODUKTIVNE KARAKTERISTIKE HIBRIDA POLJSKOG LANDRASA I VELIKE BELE POLJSKE SVINJE
}

\author{
NAPIERAŁA Dorota, KAWĘCKA Maria, JACYNO Eugenia, MATYSIAK Beata, \\ KOLODZIEJ-SKALSKA Anita
}

Cilj studije je bio da se ispita potencijalna povezanost između varijanti BF gena i broja oprašenih prasića kod krmača u slučaju hibrida poljski landras x velika bela poljska. Radi detekcije polimorfizma u BF genu, primenjen je PCR-RFLP metod pri čemu su korišćeni specifični prajmeri i SmaI enzim. Identifikovana su dva alela, T i C pri čemu je učestalost bila 0,68 odnosno 0,32, a koji su uslovljavali tri genotipa: TT, TC i CC čije su učestalosti bile $0,49,0,37$ i 0,14 . Analize povezanosti između različitih genotipova BF gena i odabranih reproduktivnih rizika, ukazale su da postoje značajne razlike. Krmače sa TT genotipom, u BF lokusu, imale su značajno veći broj $(10,24)$ žive prasadi prilikom prvog prašenja u poređenju sa krmačama koje su imale CC genotip $(7,13)$. 